\title{
ANIMAIS DE ESTIMAÇÃO EM CONDOMÍNIO EDILÍCIO: UM ESTUDO COM BASE NO DIREITO DE PROPRIEDADE
}

\author{
VICTOR CONTE ANDRÉ 1
}

\begin{abstract}
${ }^{1}$ Mestre em Ciências Sociais pela Universidade Vila Velha, especialista em Direito Civil e Processual Civil pela Faculdade de Direito Prof. Damásio de Jesus, especialista em Direito Administrativo pela Faculdade da Região Serrana e bacharel em Direito pela Universidade Vila Velha. Professor concursado da Faculdade de Ensino Superior de Linhares e advogado.victor.conte.adv@gmail.com.
\end{abstract}

\section{RESUMO}

O presente trabalho tem o objetivo investigar a respeito da legalidade e dos limites das normas condominiais restritivas de animais de estimação em condomínio edilício, apresentando uma conclusão de como o assunto deve ser tratado e solucionado na prática. Para o desenvolvimento da pesquisa, foi utilizado o método da revisão bibliográfica, por meio de um estudo cuidadoso da legislação, de livros dos mais renomados autores e da jurisprudência. $\mathrm{O}$ tema é atual e possui destacada relevância, pois um número cada vez mais alto de pessoas se encontra vivendo em condomínio edilício, ao passo em que houve um aumento do número de animais de estimação nesse tipo de imóvel, havendo contradições entre as regras condominiais restritivas de animais domésticos e o direito de propriedade do condômino. A conclusão que se chega é que se figura como abusiva a restrição estabelecida se inexiste qualquer fato que revele o animal representar efetivo prejuízo à saúde, ao sossego e à segurança dos demais condôminos ou moradores do prédio. A proibição constitui uma violação ao livre exercício do direito de propriedade. É direito do proprietário ou possuidor da unidade ter um animal de estimação em sua residência, podendo se deslocar com o seu animal pelas áreas de acesso ao logradouro público, de modo a entrar e sair do prédio, sob o controle dos instrumentos apropriados, tais como o uso de coleira e guia e, quando recomendado, da focinheira. O reconhecimento do direito do condômino, ou morador, de criar em sua unidade animais domésticos e com estes circular pelas áreas comuns de acesso às vias públicas não significa que o dono do animal esteja desobrigado de preservar a saúde, o sossego e a segurança dos demais habitantes do prédio. Tampouco significa que tal direito possa ser exercido irrestritamente.

Palavras-chave: Animais de Estimação; Condomínio Edilício; Direito de Propriedade; Função Social da Propriedade; Proibição e Restrição.

\section{PETS IN CONDOMINIUM: A STUDY BASED ON PROPERTY LAW}

\begin{abstract}
The present work aims to investigate the legality and limits of condominium rules restricting pets in a condominium, presenting a conclusion of how the subject should be treated and resolved in practice. For the development of the research, the bibliographic
\end{abstract}


review method was used, through a careful study of the legislation, books of the most renowned authors and jurisprudence. The theme is current and has outstanding relevance, since an increasing number of people are living in a condominium while there has been an increase in the number of pets in this kind of property, with contradictions between the restrictive condominium rules of domestic animals and the residents's property right. The conclusion reached is that the established restriction is considered abusive if there is no concrete fact that reveals the animal to represent an effective damage to the health, peace and security of the other residents of the building. The prohibition constitutes a violation of the free exercise of the property. It is the right of the owner of the unit to have a pet in his residence, and he can move with his animal through the access areas to the public street, in order to enter and exit the building, under the control of the appropriate instruments, such as the use of a collar and guide and, when recommended, a muzzle. The recognition of the right of the owner, or resident, to raise domestic animals in his unit and with them circulate through the common areas of access to public roads does not mean that the owner of the animal is not obliged to preserve the health, peace and security of others residents. And it does not mean that such a right can be exercised unrestrictedly.

Keywords: Condominium; Pets; Prohibition and Restriction; Property Right; Social Function of Property.

\section{INTRODUÇÃO}

A criação de animais domésticos em imóveis urbanos aumentou consideravelmente. De acordo com os dados do Instituto Brasileiro de Geografia e Estatística, já existem mais cães de estimação nos lares brasileiros do que crianças, sendo que o Brasil já ocupa a posição de quarto maior país em número de animais de estimação e o segundo em relação ao número de cães, gatos e aves canoras e ornamentais (IBGE, 2010).

A indústria e o mercado de produtos e serviços para animais de estimação geram uma movimentação financeira bilionária no Brasil, que já ocupa a segunda posição no mercado mundial, conforme os dados da Associação Brasileira da Indústria de Produtos para Animais de Estimação (ABINPET, 2019).

Ao mesmo tempo, nos grandes centros urbanos, muitas pessoas se encontram vivendo em condomínios. A busca por segurança, praticidade e divisão de despesas são alguns dos fatores que motivam as pessoas a conviver com várias outras em um espaço com pouca extensão.

Nesse contexto, surge a questão dos animais de estimação em condomínio edilício, uma vez que o assunto encontra divergência de opiniões, havendo a 
necessidade de pesquisar a respeito da possibilidade ou não do condomínio criar restrições quanto aos moradores possuírem em suas unidades animais domésticos.

É bastante comum encontrar em convenções condominiais cláusulas proibitivas de animais de estimação nos apartamentos. Ou, então, cláusulas limitadoras de porte de animais. A partir daí, decorrem uma série de conflitos, que, na sua maioria, demandam a intervenção do judiciário.

Busca-se, com o presente artigo, pesquisar a respeito da legalidade e dos limites das normas condominiais sobre temática, apresentando uma conclusão de como o assunto deve ser tratado e resolvido na prática.

O tema é atual e possui destacada relevância, pois um número cada vez mais alto de pessoas se encontra vivendo em condomínio edilício ao passo em que houve um aumento do número de animais de estimação nesse tipo de imóvel, havendo contradições entre as regras condominiais restritivas de animais domésticos e o direito de propriedade do condômino.

Em um primeiro momento, é tratado sobre a propriedade e a sua função social, permitindo uma melhor compreensão do cerne da questão, que é a propriedade e o jus utendi e o atributo da exclusividade em relação a função social da propriedade como fatores a ser considerados na investigação do dever do proprietário em face de terceiros.

Posteriormente, é realizada uma explanação sobre as limitações ao uso da coisa nas relações de vizinhança, tendo em vista as normas limitadoras do uso da propriedade contidas nessa seara.

Por último, investiga-se a validade ou não das cláusulas de proibição e de restrição de animais de estimação em condomínio à luz da jurisprudência e das normas de condomínio e vizinhança, bem como de que maneira o dono do animal deve proceder no caso de aplicação de multas pelo condomínio ou outras sanções.

Este estudo foi realizado a partir de uma revisão bibliográfica, por meio de pesquisa cuidadosa da legislação, de livros dos mais renomados autores e da jurisprudência. Foram selecionados autores com prestígio e reconhecimento pela comunidade jurídica, sendo que as obras foram devidamente referenciadas de acordo com as diretrizes para apresentação de trabalhos à equipe editorial da Revista Pensar Acadêmico. 


\title{
2 DA PROPRIEDADE E DA SUA FUNÇÃO SOCIAL
}

A propriedade consiste em uma situação jurídica, dinâmica e complexa, estabelecida entre o dono e a coletividade. O Código Civil não define o que vem a ser propriedade, mas apresenta as faculdades que compõem o exercício de tal direito. $\mathrm{O}$ art. 1.228 do Código Civil confere ao seu titular a faculdade de usar, gozar e dispor da coisa, e o direito de reavê-la do poder de quem quer que injustamente a possua ou detenha.

\begin{abstract}
Os aspectos são desdobrados em econômico ou interno e jurídico ou externo. $\mathrm{O}$ aspecto econômico ou interno compreende o direito de utilizar a coisa segundo a sua destinação econômica (uso), de obter dela os seus frutos (fruição) e de alienar, transformar ou destruir a mesma (disposição). O aspecto jurídico ou externo comporta o direito de afastar outra pessoa da esfera de assenhoramento do proprietário (exclusão) e de perseguir a coisa onde quer que ela se encontre, podendo reavê-la das mãos de quem injustamente a possua ou detenha (sequela). (MORAES, 2020, p. 183).
\end{abstract}

A propriedade presume-se plena e exclusiva, até prova em contrário, conforme art. 1.231 do Código Civil. A plenitude confere o exercício de todas as faculdades da propriedade ao seu titular, ressalvadas situações legais específicas. A exclusividade diz respeito a presunção de que somente o proprietário é quem exerce sobre a coisa todos os poderes assegurados pela lei, excluindo os não titulares. E os poderes inerentes à propriedade, em princípio, são perpétuos, ou seja, não decaem com o transcurso do tempo, permanecendo o seu titular como dono da coisa até que assim o deseje ou que uma nova relação ou situação jurídica venha a modificar tal circunstância.

$\mathrm{O}$ art. 5 XXII, da Constituição de 1988, garante o direito de propriedade a todas as pessoas. E pelo seu art. $5^{\circ}$, XXIII, a propriedade atenderá a sua função social.

A compreensão do que vem a ser a função social necessita de um entendimento sobre os próprios atributos da propriedade, provenientes do ius utendi, fruendi et abutendi (direito de usar, fruir e abusar), que compõem a acepção romana de propriedade, projeção da Lei das XII Tábuas. Assim, será possível desenvolver o cerne da questão, que é a propriedade e o jus utendi e o atributo da exclusividade em relação a função social da propriedade a ser considerados na investigação do dever do proprietário em face de terceiros. 
A faculdade de usar a coisa diz respeito à possibilidade de o proprietário aproveitar-se da coisa, valendo-se das suas qualidades em conformidade com a sua destinação. Significa conservar a coisa à sua própria disposição para servir-se dela.

A faculdade de fruir, ou gozar, diz respeito à oportunidade que o proprietário tem de beneficiar-se economicamente com a coisa, por meio da aferição de rendas ou percepção dos produtos e frutos civis e industriais.

No que diz respeito ao direito de abusar, o Código de Napoleão, que entrou em vigor em 21 de março de 1804, embasado pela ideia romana, previa que "A propriedade é o direito de gozar e dispor das coisas da maneira a mais absoluta, sem poder fazer o que a lei ou os regulamentos proíbem”.

\begin{abstract}
Como sabido, esse Código e as ideias da Revolução repercutiram em todos os ordenamentos que se modelaram no Código Civil francês, incluindo-se a grande maioria dos códigos latino-americanos. Esse exagerado individualismo perde força no século XIX com a revolução e o desenvolvimento industrial e com as doutrinas socializantes. Passa a ser buscado um sentido social na propriedade. (VENOSA, 2020, p. 172).
\end{abstract}

Na contemporaneidade, o proprietário não possui mais a faculdade de fazer com a coisa o que bem quiser. A propriedade sofre limitações legais, mormente em razão da sua função social.

\begin{abstract}
Antigamente essa característica era bem mais acentuada, de tal sorte que a propriedade era considerada, no direito romano, usque ad inferos e usque ad sidera, ou seja, dos céus às profundezas da terra. Ocorre que hoje a lei restringe este direito, em tese ilimitado, seja em razão de limitações específicas, seja através da função social da propriedade. Consideramos que a função social, a par de limitações específicas, tais como as limitações administrativas (servidões, requisições, ocupações e desapropriações) e civis (por exemplo, os direitos reais sobre coisa alheia) hoje, faz parte da construção jurídica do direito de propriedade. (SCAVONE JUNIOR, 2020, p. 16).
\end{abstract}

O direito de propriedade não pode ser exercido de forma abusiva, mas de acordo com os limites impostos pelo seu fim econômico ou social, pela boa-fé ou pelos bons costumes. Conforme art. 1.228, § $3^{\circ}$, do Código Civil, são defesos os atos que não trazem ao proprietário qualquer comodidade, ou utilidade, e sejam animados pela intenção de prejudicar outrem. 
O Código Civil ainda confere ao proprietário a faculdade de dispor da coisa, que significa a possiblidade de dar à coisa uma finalidade, sendo isso uma adaptação do ius abutendi considerando a realidade social. Somado a isso, ao proprietário é conferido o poder de reivindicar, que significa reavê-la do poder de quem quer que injustamente a possua ou detenha.

\begin{abstract}
Assim, dizer que propriedade é o direito de exercer com exclusividade o uso, a fruição, a disposição e a reivindicação de um bem, é dizer muito pouco. É esquecer os deveres do dono e os direitos da coletividade. Ao esquecer os direitos da coletividade, ou seja, do outro, do próximo, estamos excluindo-o. É esquecer, ademais, o caráter dinâmico da propriedade, que consiste em relações que se movimentam, que se transformam no tempo e no espaço. É esquecer que a propriedade deve ser relação em cooperação (dono + coletividade), não em contradição (dono x coletividade). Sem essa visão da propriedade como fenômeno dinâmico, em cooperação, é impossível se falar em função social e, muito menos, em função econômica. (FIUZA, 2014, p. $561)$.
\end{abstract}

$\mathrm{O}$ art. $1.228,1^{\circ}$, do Código Civil, dispõe que o direito de propriedade deve ser exercido em consonância com as suas finalidades econômicas e sociais e de modo que sejam preservados, de conformidade com o estabelecido em lei especial, a flora, a fauna, as belezas naturais, o equilíbrio ecológico e o patrimônio histórico e artístico, bem como evitada a poluição do ar e das águas.

Entender a função social da propriedade não é tarefa fácil. Mais difícil ainda é apresentar a sua definição.

Função traz a ideia de finalidade de um modelo jurídico, o papel a ser desempenhado por um instituto. O cumprimento com a função social de um direito ocorre quando o seu titular, ao exercê-lo, atuar de acordo com as exigências sociais.

\footnotetext{
A função social é um princípio inerente a todo direito subjetivo. A evolução social demonstrou que a justificação de um interesse privado muitas vezes é fator de sacrifício de interesses coletivos. Há muito, não mais se admite que a satisfação de um bem individual seja obtida "às custas da desgraça alheia". Portanto, ao cogitarmos da função social, introduzimos no conceito de direito subjetivo a noção de que o ordenamento jurídico apenas concederá merecimento à persecução de um interesse individual se este for compatível com os anseios sociais que com ele se relacionam. Caso contrário, o ato de autonomia privada será censurado em sua legitimidade. (FARIAS, NETTO \& ROSENVALD, 2017, p. 1.404-1405)
}

A propriedade deve, portanto, cumprir com uma função social e, de tal modo, suporta uma série de restrições que se configuram como uma contraprestação perante a 
coletividade em razão do exercício exclusivo de poderes sobre uma determinada coisa, garantindo assim o próprio bem-estar social de seus familiares, de seus empregados e da coletividade (FIUZA, 2014).

\begin{abstract}
Assim, a lei não permite que uma parte, ao exercer um direito, prejudique a outra, mormente se esse exercício não traz qualquer comodidade ou utilidade, mas, pelo contrário, é animado apenas pela intenção de prejudicar. Segundo a doutrina, trata-se de evolução do direito, que passa a observar o interesse comum, sobrepondo o direito da coletividade ao mesquinho interesse de um só. (SCAVONE JUNIOR, 2020, p. 17).
\end{abstract}

Do exposto, percebe-se que o que se visa coibir é o abuso do direito de propriedade e a inobservância à sua função social.

O exercício do direito, em consonância com os limites que recaem sobre a propriedade e mediante o respeito ao interesse comum e aos anseios sociais, não pode sofrer intervenções e restrições injustas, sob pena de configurar violação do direito de seu titular, especialmente um direito fundamental como a propriedade.

\title{
3 DAS LIMITAÇÕES AO USO DA COISA NAS RELAÇÕES DE VIZINHANÇA
}

Das diversas restrições e proibições no direito de propriedade, ressalta-se as regras de vizinhança, de modo que o proprietário, ou o possuidor, está impedido de exercer o seu direito de forma prejudicial à saúde, ao sossego e à segurança dos que habitam prédios vizinhos (FARIAS e ROSENVALD, 2015).

\begin{abstract}
A propriedade deve ser usada de tal maneira que torne possível a coexistência social. Se assim não se procedesse, se os proprietários pudessem invocar uns contra os outros seu direito absoluto e ilimitado, não poderiam praticar qualquer direito, pois as propriedades se aniquilariam no entrechoque de suas várias faculdades. [...] Os recíprocos direitos e deveres dos vizinhos podem ser de natureza positiva (fazer) e negativa (não fazer). No primeiro caso, temos como exemplo a obrigação de proceder à demarcação do seu prédio junto ao vizinho e, no segundo, a obrigação de usar de modo anormal da posse ou propriedade, ferindo a segurança, sossego ou saúde dos vizinhos. (MELO, 2019, p. 197)
\end{abstract}

Interferências prejudiciais à segurança, ao sossego e à saúde dos vizinhos configuram o uso anormal da propriedade e sujeita o proprietário a uma série de 
sanções. Portanto, o proprietário é livre para exercer o seu direito, desde que atento às regras da boa convivência e à finalidade social.

É preciso ter cuidado ao apurar um determinado conflito de vizinhança, sendo necessário que os atos praticados pelo vizinho sejam realmente caracterizadores de interferências prejudiciais ao direito alheio, sob pena de intervenção injustificada no direito de propriedade.

Com efeito, o simples fato do convívio entre propriedades próximas acaba por gerar conflitos. As interferências são consequências naturais da vida em sociedade, cabendo ao intérprete distinguir as que são consideradas aceitáveis e podem ser praticadas daquelas que, ao contrário, não apresentam este caráter e devem ser reprimidas pelo ordenamento jurídico. Nessa esteira, define-se a relação de vizinhança como relação de confronto e não de cooperação, em que a satisfação do interesse de um proprietário implica restrições ao interesse do proprietário vizinho (MONTEIRO FILHO, RENTERIA e TEPEDINO, 2020, p. 201).

Proíbem-se, assim, as interferências considerando-se a natureza da utilização, a localização do prédio, atendidas as normas que distribuem as edificações em zonas, e os limites ordinários de tolerância dos moradores da vizinhança, nos termos do art. 1.277, parágrafo único, do Código Civil.

Há incontáveis situações que repugnam ao bom-senso e contradizem os padrões normais de comportamento. Todos somos obrigados a suportar as emissões e repercussões que nos vêm do prédio vizinho. Nossa tolerância, porém, cessa quando o mau uso deste prédio torna-se nocivo à saúde, à segurança e ao sossego dos que habitam em prédios contíguos. Em outros termos, o uso irregular ou anormal da propriedade equivale ao uso abusivo e intolerável. Aquilo que se mantém nos níveis da normalidade não é punível, e deve suportar o vizinho. (RIZZARDO, 2016, p. 500).

O Enunciado 319 do Conselho de Justiça Federal manifesta que "A condução e a solução das causas envolvendo conflitos de vizinhança devem guardar estreita sintonia com os princípios constitucionais da intimidade, da inviolabilidade da vida privada e da proteção ao meio ambiente".

Uma vez caracterizada a interferência prejudicial à segurança, ao sossego e à saúde dos que habitam um prédio, provocadas pela utilização de propriedade vizinha, o seu proprietário ou possuidor tem o direito de fazer cessá-la, conforme art. 1.277, caput, do Código Civil. 
O uso da coisa, conforme a sua destinação, sem a verificação de prática de atos configuradores de interferências prejudiciais à saúde, ao sossego e à segurança dos vizinhos, revela atenção e cumprimento com a função social da propriedade, tendo em vista a atuação de acordo com as exigências sociais. E qualquer medida restritiva ao direito de propriedade nessas conjunturas seria uma violação ao direito do seu titular.

Por fim, as regras de vizinhança são aplicáveis não apenas às propriedades contíguas, mas pressupõe a localização de propriedades em áreas próximas, de tal forma que o uso de uma venha a interferir no de outras (NADER, 2016). Tais regras e restrições inerentes à vizinhança são aplicáveis, inclusive, em condomínios por unidades autônomas.

\section{DAS CLÁUSUlas de PROIBIÇÃo E DE RESTRIÇÃo DE ANIMAIS DE ESTIMAÇÃO EM CONDOMÍNIO}

Existem situações em que mais de uma pessoa passa a ter o exercício do direito de propriedade sobre uma determinada coisa, o que se denomina condomínio geral (TARTUCE, 2013).

Pode haver, em edificações, partes que são propriedade exclusiva, e partes que são propriedade comum dos condôminos. Esse tipo de situação é denominado de condomínio edilício ou por unidades autônomas.

\footnotetext{
É típico instituto da contemporaneidade, especialmente nos grandes centros urbanos, devido às transformações ocorridas na sociedade com o êxodo rural e a concentração urbana. Cuida-se de instituto que combina traços de propriedade individual e exclusiva e de condomínio, eis que há condomínio forçado incidente no terreno e nas partes do edifício que não podem ser privativas em harmonia com a propriedade privada e exclusiva sobre cada uma das unidades. [...] Cada condômino será considerado proprietário exclusivo de sua unidade (apartamento, sala, escritório, casa, conjunto de salas ou escritórios, andares) e, em razão disso, poderá exercer poderes dominiais com exclusividade sobre ela (GAMA, 2011, p. 396).
}

As partes suscetíveis de utilização independente, tais como apartamentos, escritórios, salas, lojas e sobrelojas, com as respectivas frações ideais no solo e nas outras partes comuns, sujeitam-se a propriedade exclusiva, podendo ser alienadas e gravadas livremente por seus proprietários, exceto os abrigos para veículos, que não 
poderão ser alienados ou alugados a pessoas estranhas ao condomínio, salvo autorização expressa na convenção de condomínio.

Já o solo, a estrutura do prédio, o telhado, a rede geral de distribuição de água, esgoto, gás e eletricidade, a calefação e a refrigeração centrais, e as demais partes comuns, inclusive o acesso ao logradouro público, são utilizados em comum pelos condôminos, não podendo ser alienados separadamente, ou divididos.

Em resumo, haverá propriedade individual de cada unidade, seja sala, apartamento, loja, garagem, casa etc., e propriedade em condomínio do solo e partes comuns, tais como paredes, fundações, saguão de entrada, corredores, portas etc. O solo e as partes comuns são divididas em frações ideais, pertencentes a cada um dos condôminos (FIUZA, 2014, p. 1016).

O condomínio por unidades autônomas é regulado externamente pelo Código Civil e internamente pela convenção de condomínio. A convenção de condomínio:

Trata-se de norma interna na qual são estipulados os direitos e deveres recíprocos dos condôminos. Seria uma espécie de constituição privada dos comproprietários, haja vista a sua força cogente apta a pautar comportamentos individuais reguladores da convivência geral. Pessoas com diversa formação cultural e nível social heterogêneo deverão se submeter a padrões mínimos de civilidade (FARIAS e ROSENVALD, 2015, p. 613).

É, portanto, "documento escrito, no qual se preveem os direitos e deveres dos condôminos. Também chamada de estatuto, ou pacto constitutivo, regula toda a vida do condomínio" (FIUZA, 2014, p. 1016).

A convenção de condomínio, de caráter institucional, deve ser subscrita pelos titulares de, no mínimo, dois terços das frações ideais e torna-se, desde logo, obrigatória para os titulares de direito sobre as unidades, ou para quantos sobre elas tenham posse ou detenção, conforme art. 1.331 do Código Civil. Para ser oponível contra terceiros, a convenção do condomínio deverá ser registrada no Cartório de Registro de Imóveis.

A convenção é obrigatória para todos os moradores do edifício. Sendo assim, as cláusulas que estabelecem a proibição, ou a limitação de porte, de animal de estimação na unidade imobiliária possuem validade jurídica?

Cumpre destacar que o direito é resultado da vida em sociedade e a pressupõe. Compreende um conjunto de institutos destinados a assegurar o exercício dos direitos sociais e individuais, a liberdade, a segurança, o bem-estar, o desenvolvimento, a 
igualdade e a justiça. Assim sendo, o "direito é a soma das condições de existência social, no seu amplo sentido, assegurada pelo Estado através da coação" (JHERING, 1992, p. 3-4).

Uma das características da copropriedade edilícia consiste no fato de os condôminos, além de poderem usar, gozar, reivindicar e dispor de suas unidades imobiliárias, terem o direito de usar as partes comuns, de acordo com a sua destinação e nos termos da convenção, sem impedir a prática de igual direito por parte dos demais condôminos.

\begin{abstract}
Como se nota, a convenção é regida pelo princípio da força obrigatória da convenção (pacta sunt servanda). Porém, na realidade contemporânea, não se pode esquecer que tal preceito não é absoluto, encontrando fortes limitações nas normas de ordem pública, nos preceitos constitucionais e em princípios sociais, caso de boa-fé objetiva (art. 422, do CC) e da função social dos pactos e contratos (art. 421, do CC). Deve a convenção condominial, especialmente as suas cláusulas, ser analisada de acordo com a realidade que a cerca (ética da situação), sendo essa a expressão da socialidade e da eticidade, pilares conceituais da atual codificação civil e do Direito Privado Contemporâneo (TARTUCE, 2014b, p. 291).
\end{abstract}

A convenção de condomínio configura-se como um acordo de vontade que estabelece direitos e obrigações entre os proprietários e possuidores, atuais e futuros. Constitui, portanto, um negócio jurídico celebrado entre particulares e, sendo assim, não prevalece sobre a lei; pelo contrário, deve ser elaborada de acordo as normas jurídicas.

A cláusula aprovada em assembleia de condômino realizada de acordo com as formas previstas na lei e na convenção pode apresentar diferentes aspectos quanto à legalidade, cita-se alguns: a) a norma contida na cláusula possui validade e eficácia por atender às finalidades para a qual se propõe, sendo o seu objeto lícito, possível, determinado ou determinável; b) o conteúdo afronta determinada norma jurídica, ocasião em que a cláusula é nula por causa da sua ilegalidade; c) a cláusula se reveste de uma aparência de regra legal, porém, o seu conteúdo está além do que pode ser considerado razoável, ultrapassando os limites da boa-fé e da função social da propriedade, resultando em restrição ao livre exercício do direito de propriedade, caracterizando, assim, o abuso de direito.

O abuso de direito desponta quando seu titular, ao exercê-lo, excede manifestamente os limites impostos pelo seu fim econômico ou social, pela boa-fé ou pelos bons costumes, como previsto no art. 187 do Código Civil. 
Compreende "os excessos colocados em prática pela pessoa no exercício de seus direitos" (RIZZARDO, 2011, p. 112). Desse modo, o abuso de direito é caracterizado pelo "seu anormal exercício, assim entendido aquele que se afasta da ética e da finalidade social ou econômica do direito" (CAVALIERI FILHO, 2014, p. 203). Tais excessos são prejudiciais à coesão social e configuram ato ilícito.

No abuso de direito, "a atitude do agente está aparentemente respaldada pela norma jurídica, mas o seu titular excede manifestamente os limites indicados pela norma. Trata-se de um ilícito funcional" (ANDRÉ, 2019, p. 38).

Na teoria e na prática, a grande dificuldade está em saber os limites de licitude das estipulações da convenção condominial, sendo pertinente a análise de alguns casos concretos comuns ao mercado imobiliário. Como primeira ilustração, surge polêmica referente à presença de animais nas dependências do condomínio. Três situações podem ser apontadas, pois usuais na prática: a) a convenção de condomínio proíbe a estada de animais; b) a convenção é omissa sobre o assunto; c) a convenção permite os animais no condomínio. Nos dois últimos casos, em regra, a permanência dos animais é livre, a não ser que o animal seja perturbador ou incompatível com o bemestar e a boa convivência dos condôminos. Ademais, mesmo nos casos em que há proibição na convenção de condomínio, a boa jurisprudência tem entendido que é permitida a permanência do animal de estimação, desde que ele não perturbe o sossego, a saúde e a segurança dos demais coproprietários (TARTUCE, 2014b, p. 291-292).

O art. 1.335, I, do Código Civil, preconiza que é direito do condômino usar, fruir e livremente dispor das suas unidades. Por óbvio, a utilização da sua unidade deve ser em consonância com a finalidade dela.

Sendo assim, a elaboração de cláusulas na convenção de condomínio proibindo animais de estimação, ou limitando o seu porte, nas unidades imobiliárias residenciais, configura excesso normativo que viola o direito do proprietário de usar e fruir livremente da sua unidade de acordo com a sua destinação, como assegurado pelo Código Civil.

As regras de condomínio sobre animais de estimação, assim como as demais normas condominiais, devem estar embasadas pelos princípios do sossego, da salubridade e da segurança, ou bons costumes, elencados no art. 1.336, IV, do Código Civil, não sendo razoável que a vontade de um grupo prevaleça sobre um direito reconhecido por lei. Eventuais multas aplicadas ao condômino nessas conjunturas são nulas (ANDRÉ, 2019, p. 39-40). 
Mesmo que a convenção do condomínio venha a proibir a permanência de animais no edifício e que o assunto tenha sido decido por assembleia, nada obsta a adequação social dessa manifestação ao legítimo direito de limitação ao exercício da propriedade, cuja intervenção deve ser mínima e somente aplicável quando indispensável à manutenção da convivência social.

O Enunciado 566 do Conselho de Justiça Federal expressa que "A cláusula convencional que restringe a permanência de animais em unidades autônomas residenciais deve ser valorada à luz dos parâmetros legais de sossego, insalubridade e periculosidade".

O Tribunal de Justiça do Estado de Minas Gerais decidiu que o ônus da prova quanto ao animal ser prejudicial ao sossego, à segurança ou à saúde dos vizinhos incumbe a quem alega tal evento.

\begin{abstract}
EMENTA: APELAÇÃO CÍVEL - AÇÃO ORDINÁRIA - PEDIDO COMINATÓRIO - CONDOMÍNIO EDILÍCIO - CONVENÇÃO DE CONDOMÍNIO - MANUTENÇÃO DE ANIMAIS DOMÉSTICOS EM UNIDADE AUTÔNOMA - VEDAÇÃO CONDICIONADA À COMPROVAÇÃO DE PREJUDICIALIDADE AO SOSSEGO, À SAÚDE E À SEGURANÇA DOS VIZINHOS - ÔNUS DA PROVA - PARTE AUTORA - IMPROCEDÊNCIA DO PEDIDO. É cediço que a convenção de condomínio, uma vez aprovada, obriga a todos os condôminos, nos termos do art. 1.333 do Código Civil, sendo certo que o condomínio pode estabelecer regras limitativas do direito de vizinhança, conforme autoriza a Lei $\mathrm{n}^{\circ}$ 4.591/64. Entretanto, a jurisprudência tem admitido a flexibilização de cláusula vedatória, de modo a possibilitar a permanência de animais que não causem incômodos, não perturbem o sossego e não constituam ameaça à saúde e à segurança dos demais moradores. Incumbe à parte autora comprovar, nos termos do inciso I do art. 333 do CPC/73, que a manutenção dos animais na unidade autônoma da parte ré é prejudicial ao sossego, à segurança ou à saúde dos vizinhos, sem o que impossível o acolhimento de sua pretensão cominatória (MINAS GERAIS, 2016, on-line).
\end{abstract}

O Superior Tribunal de Justiça decidiu, por unanimidade, que o condomínio não pode restringir que os moradores tenham animais de estimação em suas unidades se estes não causarem incômodos, perturbarem o sossego ou não constituírem ameaça à saúde e à segurança dos demais habitantes do prédio, determinando a flexibilização da referida cláusula, de modo a possibilitar a permanência dos animais domésticos.

EMENTA: RECURSO ESPECIAL. CONDOMÍNIO. ANIMAIS. CONVENÇÃO. REGIMENTO INTERNO. PROIBIÇÃO. FLEXIBILIZAÇÃO. POSSIBILIDADE. 1. Recurso especial interposto contra acórdão publicado na vigência do Código de Processo Civil de 2015 
(Enunciados Administrativos $\mathrm{n}^{\circ} \mathrm{s} 2$ e 3/STJ). 2. Cinge-se a controvérsia a definir se a convenção condominial pode impedir a criação de animais de qualquer espécie em unidades autônomas do condomínio. 3. Se a convenção não regular a matéria, o condômino pode criar animais em sua unidade autônoma, desde que não viole os deveres previstos nos arts. 1.336 , IV, do CC/2002 e 19 da Lei $n^{0}$ 4.591/1964. 4. Se a convenção veda apenas a permanência de animais causadores de incômodos aos demais moradores, a norma condominial não apresenta, de plano, nenhuma ilegalidade. 5. Se a convenção proíbe a criação e a guarda de animais de quaisquer espécies, a restrição pode se revelar desarrazoada, haja vista determinados animais não apresentarem risco à incolumidade e à tranquilidade dos demais moradores e dos frequentadores ocasionais do condomínio. 6. Na hipótese, a restrição imposta ao condômino não se mostra legítima, visto que condomínio não demonstrou nenhum fato concreto apto a comprovar que o animal (gato) provoque prejuízos à segurança, à higiene, à saúde e ao sossego dos demais moradores. 7. Recurso especial provido (BRASIL, 2019, on-line).

De acordo com a decisão, se a convenção não regular a matéria, sendo omissa quanto à possibilidade de o condômino ter ou não um animal de estimação em sua unidade, então o morador pode criar animais em sua propriedade. No caso de animais causadores de sérios incômodos aos demais condôminos, a questão deve ser analisada caso a caso, prevalecendo o que for aprovado em assembleia. Já no caso de cláusula proibitiva de criação e guarda de animais, a corte decidiu que tal proibição se revela desarrazoada, pois certos animais não apresentam risco à incolumidade e à tranquilidade dos demais moradores.

Toda e qualquer a restrição genérica, sem uma fundamentação legítima, deve ser afastada, possibilitando ao morador o exercício regular do seu direito de usar livremente da sua unidade.

Portanto, é legítimo que o proprietário venha negar-se a cumprir com a regra restritiva de animais de estimação estabelecida na convenção caso a permanência do seu animal não resultar em qualquer prejuízo à saúde, ao sossego e à segurança dos demais habitantes do edifício.

Obtempere-se que a convenção condominial não poderá criar restrições indevidas aos condôminos, pois as limitações só se justificam quando correspondem à aplicação do princípio genérico que atende ao bem comum e impede o mau uso da propriedade nas relações de vizinhança, por ofensa à saúde, à segurança e ao sossego dos demais condôminos. Ou seja: a convenção condominial é lei interna a ser observada por todos, mas as suas disposições devem guardar um mínimo de bom senso, sob pena de restrição à garantia fundamental do direito de propriedade (art. $5^{\circ}, \mathrm{XXII}$, da CF). As cláusulas que não guardem harmonia com a Constituição Federal e a razoabilidade inserem-se no abuso de direito, eis que ofendem a finalidade 
para o qual se instituiu o condomínio (FARIAS e ROSENVALD, 2015, p. 617-619).

Inclusive, mesmo nos casos em que o animal venha a causar algum incômodo sem ocorrências de maiores transtornos significativos ao cotidiano dos moradores, tais como fazer suas necessidades fisiológicas em áreas comuns ou latir eventualmente, é irrazoável exigir que o animal seja retirado do prédio. O condomínio pode até fazer uso das suas prerrogativas de notificar e multar o condômino, se for o caso e a depender da gravidade da ocorrência e da frequência na interferência prejudicial.

Mas a retirada do animal do prédio é medida extrema e deve ser a solução em casos específicos e de maior gravidade.

Portanto, o animal que se encontra sob a posse de um ser humano tem o direito de ter seus interesses vitais considerados pela norma jurídica e, neste sentido, o seu detentor possui o dever de zelar pelo bem-estar do animal, preservando a sua saúde, dando-lhe alimentação e boa qualidade de vida (MEDEIROS, 2019, p. 44).

No que diz respeito às áreas comuns, a convenção pode estabelecer limites ou proibições quanto à presença de animais de estimação, uma vez que esses espaços pertencem a todos os condôminos e, sendo assim, o interesse do grupo deverá prevalecer sobre a vontade individual.

A ressalva diz respeito às áreas de locomoção e acesso à unidade, pois o 1.331, $\S 4^{\circ}$, do Código Civil, dispõe que nenhuma unidade imobiliária pode ser privada do acesso ao logradouro público.

Assim, configura conduta abusiva a aprovação de cláusula condominial que determina que o animal de estimação seja transportado no colo ou dentro de carrinhos ou a proibição do morador de fazer o uso do elevador com o animal, porquanto viola o princípio da razoabilidade, pois inexiste efetivo prejuízo à saúde, ao sossego e à segurança dos demais moradores. É direito do proprietário ou possuidor da unidade se deslocar com o seu animal pelas áreas de acesso ao logradouro público, de modo a entrar e sair do prédio, sob o controle dos instrumentos apropriados, como o uso de coleira e guia e, quando recomendado, da focinheira.

EMENTA: AGRAVO DE INSTRUMENTO. CONDOMINIO. AÇÃO DE CONCESSÃO DE TRÂNSITO. ANIMAL DE ESTIMAÇÃO. 


\begin{abstract}
ANTECIPAÇÃO DOS EFEITOS DA TUTELA. Pedido de concessão de tutela antecipada. Acolhimento. Possibilidade de o autor se deslocar com seu cão pelas áreas e dependências de uso comum, de modo a poder entrar e sair do prédio, sob o controle da guia, ainda que a convenção disponha que somente é autorizado a condução no colo. Princípio da razoabilidade, considerando que não há nenhum indicativo de que o cão seja violento ou cause ameaça à coletividade. Precedentes jurisprudenciais. Em decisão monocrática, dou provimento ao agravo de instrumento (RIO GRANDE DO SUL, 2015, on-line).
\end{abstract}

No caso de circulação do animal pela área comum, o que pode ocorrer é o estabelecimento de regras indicativas de como exercer tal direito, por exemplo: a condução do animal pelo elevador de serviço, sendo que só poderá ingressar no elevador quando não houver nenhuma outra pessoa já sendo transportada, salvo concordância desta; entrada e saída do animal no prédio pelo portão da garagem; dentre outras.

O condomínio também pode periodicamente exigir comprovação de que o animal esteja com vacinação e medicamentos regulares em dia, cujos certificados deverão ser exibidos à Administração do Condomínio, quando solicitado, tendo por intuito verificar se os cuidados com o animal são suficientes, não representando riscos à saúde dos demais moradores.

Se o animal sujar qualquer área do condomínio, será dever do seu dono ou detentor efetuar a limpeza, imediatamente após a sua ocorrência, por sua própria conta. Se tal fato ocorrer com habitualidade, ensejará na possiblidade da aplicação das sanções previstas na lei e no regimento interno.

As regras restritivas da presença do animal nas áreas comuns, inclusive as de lazer, devem ser flexibilizadas diante de moradores portadores de necessidades especiais que utilizam cães guias de assistência, regulamentados por lei.

\title{
5 CONCLUSÃO
}

É cada vez mais frequente a criação e a guarda de animais domésticos em condomínio edilício. Diante da discussão acerca da cláusula condominial proibitiva de animais nas respectivas unidades, figura-se como abusiva a restrição estabelecida se inexiste qualquer fato que revele o animal representar efetivo prejuízo à saúde, ao sossego e à segurança dos demais condôminos ou moradores do prédio. A proibição se constitui como uma violação ao livre exercício do direito de propriedade. 
É direito do proprietário ou possuidor da unidade ter um animal de estimação em sua residência, podendo se deslocar com o seu animal pelas áreas de acesso ao logradouro público, de modo a entrar e sair do prédio, com o uso dos equipamentos necessários.

Se alguma multa for aplicada ao condômino pelo simples fato de possuir um animal contrariando a cláusula proibitiva, tal multa é nula, podendo o condômino se abster de efetuar o seu pagamento.

A proibição e a retirada de um animal do prédio é medida extrema e deve ser a solução em casos específicos e de intensa gravidade. Mesmo no caso de pequenos incômodos sem maiores transtornos, o animal não deve ser proibido, pois é possível notificar e multar o condômino, se for o caso e a depender da gravidade da ocorrência ou frequência na interferência prejudicial.

Por fim, vale esclarecer que o reconhecimento do direito do condômino, ou morador, de criar em sua unidade animais domésticos e com estes circular pelas áreas comuns de acesso às vias públicas não significa que o dono do animal esteja desobrigado de preservar a saúde, o sossego e a segurança dos demais habitantes do prédio. Tampouco significa que tal direito possa ser exercido irrestritamente, pois o direito em questão diz respeito apenas a animais domésticos compatíveis com a natureza da propriedade residencial urbana, sendo inconcebível a ideia de que o morador possa criar em sua unidade todo e qualquer tipo de animal. O bom senso é algo que se exige tanto do condomínio quanto do morador.

\section{REFERÊNCIAS}

ABINPET - Associação Brasileira da Indústria de Produtos para Animais de Estimação. Mercado pet Brasil. Disponível em < http://abinpet.org.br/wpcontent/uploads/2019/10/abinpet_folder_2019_draft5.pdf> Acesso em: 12 abr. 2020.

ANDRÉ, Victor Conte. Introdução ao estudo da responsabilidade civil. Curitiba: Juruá Editora, 2019.

BRASIL. Superior Tribunal de Justiça, Terceira Turma, REsp no 1.783.076 - DF. Rel. Min. Ricardo Villas Bôas Cueva, j. em 14.05.2019.

CAVALIERI FILHO, Sérgio. Programa de responsabilidade civil. 11. ed. São Paulo: Atlas, 2014. 
FARIAS, Cristiano Chaves de; NETTO, Felipe Braga; ROSENVALD, Nelson. Manual de direito civil: volume único. Salvador: JusPodivm, 2017.

FARIAS, Cristiano Chaves de; ROSENVALD, Nelson. Curso de direito civil: reais. 11. ed. São Paulo: Atlas, 2015.

FIUZA, César. Direito civil: curso completo. 17. ed. São Paulo: RT, 2014.

GAMA, Guilherme Calmon Nogueira da. Direitos reais. São Paulo: Atlas, 2011.

IBGE - Instituto Brasileiro de Geografia e Estatística. Censo demográfico 2010: famílias e domicílios: resultados da amostra. Disponível em:

$<$ https://biblioteca.ibge.gov.br/visualizacao/periodicos/97/cd_2010_familias_domicilios _amostra.pdf> Acesso em: 12 abr. 2020.

JHERING, Rudolf von. A luta pelo direito. 10. ed. Rio de Janeiro: Forense, 1992.

MEDEIROS, Carla de Abreu. Direito dos animais: o valor da vida animal à luz do princípio da senciência. Curitiba: Juruá Editora, 2019.

MELO, Marco Aurélio Bezerra de. Direito civil: coisas. 3. ed. Rio de Janeiro: Forense, 2019.

MINAS GERAIS. Tribunal de Justiça do Estado de Minas Gerais, 13ª Câmara Cível, ACi 1.0105.11.003285-8/001. Rel. Des. José de Carvalho Barbosa, j. em 19.05.2016.

MONTEIRO FILHO, Carlos Edison do Rêgo; RENTERIA, Pablo; TEPEDINO, Gustavo. Fundamentos do direito civil: direitos reais. 1. ed. Rio de Janeiro: Forense, 2020 .

MORAES, Guilherme Peña de. Curso de direito constitucional. 12. ed. São Paulo: Atlas, 2020.

NADER, Paulo. Curso de direito civil: direito das coisas. v. 4. 7. ed. Rio de Janeiro: Forense, 2016.

RIO GRANDE DO SUL. Tribunal de Justiça do Estado do Rio Grande do Sul, 20a Câmara Cível, Agr. Instr. $\mathbf{n}^{\mathbf{0}}$ 70063788707. Rel. Des. Glênio José Wasserstein Hekman, j. em 06.03.2015.

RIZZARDO, Arnaldo. Parte geral do código civil. 7. ed. São Paulo: Forense, 2011.

Direito das coisas. 8. ed. Rio de Janeiro: Forense, 2016.

SCAVONE JUNIOR, Luiz Antonio. Direito imobiliário: teoria e prática. 15. ed. Rio de Janeiro: Forense, 2020. 
TARTUCE, Flávio. Manual de direito civil: volume único. 3. ed. Rio de Janeiro: Forense, 2013a.

Direito das coisas. 6. ed. São Paulo: Método, 2014b.

VENOSA, Sílvio de Salvo. Direito civil: reais. 20. ed. São Paulo: Atlas, 2020. 